\title{
Whey pretreatments before ultrafiltration
}

\author{
Tuomo Tupasela, Heikki Koskinen and Pirkko Antila
}

TUPasela, T. ${ }^{1}$, Koskinen, $\mathrm{H}^{2}{ }^{2}$ \& ANTILA, P. ${ }^{2}$ 1994. Whey pretreatments before ultrafiltration. Agricultural Science in Finland 3: 473-479. (' Agricultural Research Centre of Finland, Food Research Institute, FIN-31600 Jokioinen, Finland, and ${ }^{2}$ Department of Food Technology, FIN-00014 University of Helsinki, Finland.)

Whey is a by-product of cheesemaking. Whey dry matter contains mainly lactose, but also valuable whey proteins. The aim of this study was to develop improvements to whey protein membrane isolation processes.

In our trials $\mathrm{CaCl}_{2}$-added, $\mathrm{pH}$-adjusted and heat-treated wheys were found to have MF (microfiltration) permeate fluxes about $30 \%$ higher than in untreated MF whey. The total solids and protein content of the MF permeates decreased compared to the original wheys. UF (ultrafiltration) trials were conducted using MF whey to compare it with centrifugally separated whey. The MF whey consistently maintained an UF flux about 1.5 to 2.5 times higher than that of the separated whey. Differently treated MF whey UF permeate fluxes also showed a difference. With $\mathrm{CaCl}_{2}$ addition, $\mathrm{pH}$ adjustment and heat treatment, the UF permeate fluxes were about 20 to $40 \%$ higher than when only MF was used. The total solids content decreased in each trial. The protein content of the UF concentrate also decreased compared to the MF permeate. The $\beta$ - $\lg (\beta$-lactoglobulin) and $\alpha$-la ( $\alpha$-lactalbumin) content was almost the same in UF concentrates as in MF permeates.

Key words: clarification, microfiltration

\section{Introduction}

Whey, the liquid remaining after cheese or casein coagulation from milk, contains more than half of the non-fat solids present in the original milk, including about $20 \%$ of the protein and most of the lactose and minerals. Handling of whey has been a basic problem since the start of industrialized cheese and casein production. The earliest utilization of whey was in an unconcentrated form for animal feeding. This simple way of using whey led to sophisticated and advanced technology in concentrating and refining processes.

The stimulus for these developments came partly from the enormous pollution risk and partly from the fact that part of the solids content, such as the whey proteins $\beta$-lactoglobulin, $\alpha$-lactalbumin and bovine serum albumin, as well as the immunoglobulins are components of very high value to the dairy and food industry. One of the newest technologies used in the dairy industry is membrane technology. Reverse osmosis (RO), ultrafiltration (UF) and micro-filtration (MF) are membrane processes based on the selective permeability of one or more components of a liquid mixture through a membrane barrier.

\section{Lipoproteins}

One of the major prolems in whey protein purification are lipids. The wheys from cheesemaking and casein production vary according to the type 
of cheese and casein made, and the content of lipids also varies from $0.04 \%$ in acid whey to $0.2 \%$ in sweet whey. The residual fat in sweet whey is recovered with conventional centrifuge technology. In fat recovery the fat content in sweet whey can be reduced to a level of $0.05 \%$. Also casein wheys contain these non-centrifugeable lipids to a lower degree. The residual lipids remain in the whey after centrifugal separation because their density is higher than that of whey cream due to their association with proteinous material. The nature and origin of the residual lipid-protein complex (lipoprotein) have not been fully elucidated. The data available indicate that the residual lipids remaining after centrifuging are probably from a membraneous source (Kitchen 1974, Keenan et al. 1983, Pearce et al. 1991).

The lipids which remain in the whey are harmful. For example, it has been found that the presence of fat impairs the whipping properties of whey protein concentrate (WPC) (MCDONOUGH et al. 1974, De WIT 1984). Lipids are also susceptible to oxidation and thus contribute to an off-flavour, which is best prevented by the removal of lipids from the whey (De BOER et al. 1977). Removal of the residual lipids also increases ultrafiltration permeation fluxes (LEE and Merson 1976, Merin et al. 1983, Maubois et al. 1987).

Several improvements of the defatting process have been published. Many of the applied methods have been based on the aggregation of lipoproteins during moderate heat treatment in the presence of calcium ions (FAUQUANT et al. 1985a,b, Pierre and Fauquant 1986, Maubois et al. 1986, 1987, MaUbois 1988). Such treatment induces the formation of a fine, white precipitate and the aggregates can be removed by either centrifugation or microfiltration. The lipoprotein particles are quite large, perhaps larger than $0.4 \mu \mathrm{m}$ (Pearce et al. 1991, Pierre et al. 1992). The use of microfiltration in removing lipoproteins has two advantages over centrifugation: 1) the small amount of residual phospholipoprotein in the whey is completely removed by the MF membrane; and 2) all the bacteria present are retained in the MF retentate, and the clear defatted whey is sterile.

What should be taken into account is that defatted whey requires smaller cut-off UF membranes than normal whey for the same retention of whey proteins (MAUBoIs 1988, Merin and DaUFIN 1990).

Whey pretreatments have been developed to improve the UF flux rate. The primary objective of our research, of which this study is a part, is to develop an industrial system for whey protein separation. In this study we aimed at evaluating the effects of different whey pretreatments on ultrafiltration.

\section{Material and methods}

\section{Whey}

Fresh edam whey was obtained from the Food Research Institute's own dairy at the Agricultural Research Centre. The cheese milk had previously been pasteurized at $74^{\circ} \mathrm{C}$ for 15 seconds. After cheesemaking the whey was centrifuged and then cooled down to $2^{\circ} \mathrm{C}$ in a process tank in trials 1 , 2 and 3, and used the next day. In trials 4 and 5, the whey was used on the same day as it was manufactured.

\section{Whey pretreatment}

In trials 1,2 and $3,720 \mathrm{ml}$ of $\mathrm{CaCl}_{2}$-solution per 1001 whey $\left(\mathrm{CaCl}_{2} \times 2 \mathrm{H}_{2} \mathrm{O} 662.1 \mathrm{~g} / \mathrm{l}\right.$ a.d $\left.\mathrm{H}_{2} \mathrm{O}\right)$ was added into the whey, and the $\mathrm{pH}$ was adjusted to 7.3 with $1 \mathrm{M} \mathrm{NaOH}$ solution before heat treatment. The heat treatments in trial $1\left(50^{\circ} \mathrm{C} / 8\right.$ minutes) were performed in a mixing tank with a heating/cooling jacket, and in trials 2 and $3\left(79^{\circ} \mathrm{C} /\right.$ 20 seconds) in an Alfa Laval P20-HB plate heat exchanger with a pasteurizing capacity of $90 \mathrm{l} /$ hour. In trials 1 and 3, MF was done after the heat treatments. In trial 2, the whey was left to stand for 14 hours at $2^{\circ} \mathrm{C}$ after heat treatment before MF. In trial 4, only MF was used, and in trial 5 there was no MF before UF. The pretreatment methods are presented briefly in Table 1. 
Table 1. Edam whey pretreatments.

Trial

$1=\mathrm{CaCl}_{2}$ addition, $\mathrm{pH}$ adjustment to 7.3 , temperature treatment $50^{\circ} \mathrm{C} / 8$ minutes, $\mathrm{MF}$

$2=\mathrm{CaCl}_{2}$ addition, $\mathrm{pH}$ adjustment to 7.3 temperature treatment $79^{\circ} \mathrm{C} / 20$ seconds, standing 14 hours $/ 2^{\circ} \mathrm{C}$, $\mathrm{MF}$

$3=\mathrm{CaCl}_{2}$ addition, $\mathrm{pH}$ adjustment to 7.3 , temperature treatment $79^{\circ} \mathrm{C} / 20$ seconds, MF

$4=\mathrm{MF}$

5 = no MF before UF

Microfiltration was carried out with an APV CL $3 / 40$ microfiltration unit which had $0.2 \mu \mathrm{m}$ ceramic membranes in two modules. Each module had a membrane area of $1.4 \mathrm{~m}^{2}$. In the MF unit, the circulation speed was $5 \mathrm{~m} / \mathrm{s}$ and the temperature was kept between 20 to $30^{\circ} \mathrm{C}$ with the help of a heat exchange section in the circulation loop. The inlet pressure was 3 bars. Microfiltration was done in a batch run, with recycling. The MF unit was cleaned after each run.

\section{Ultrafiltration}

Ultrafiltration was performed each time after microfiltration with a PCI Bro MK. II ultrafiltration unit which had 25000 NMWL membranes (T6/B). The membrane material was polyacrylonitrile and the membrane area $1.733 \mathrm{~m}^{2}$. The pressure during the run was 6 bars and the temperature $20^{\circ} \mathrm{C}$. The temperature was kept constant with the help of a heat exchange section in the circulation loop. Ultrafiltration was done in a batch run. The UF unit was cleaned after each run.

\section{Analysis}

The total solids content was determined after drying for 16 hours at $102^{\circ} \mathrm{C}$. Protein was determined by the Kjeldahl method with $\mathrm{N}$ conversion of 6.38 (Tecator 1975). $\beta$-Lactoglobulin and $\alpha$ lactalbumin were determined by FPLC chromatography on a Mono Q HR 5/5 ion exchange column using the modified method of HUMBREY and Newsome (1984). Before analysis the sam-

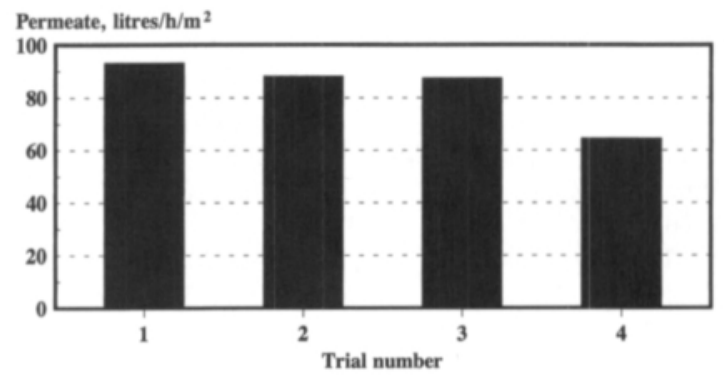

Fig. 1. MF trials with differently treated edam wheys.

ples were diluted and filtrated through a $0.2 \mu \mathrm{m}$ membrane.

\section{Results and discussion}

\section{Whey pretreatment}

We started our experiments using testing methods published earlier (FAUQUANT et al. 1985a,b, Pierre and Fauquant 1986, Maubois et al. 1987, and Maubois 1988). These systems are all based on microfiltration, but we also tried other systems when we were choosing possible pretreatment methods. The most suitable or interesting ones for our purpose are presented here. The focus in the microfiltration trials was on permeate flux and permeate composition.

The microfiltration trials were done using centrifugated whey. Figure 1, which represents the MF permeate flux in four trials, shows the differences in the performance of the wheys. Table 2

Table 2. MF and UF fluxes in the trials.

\begin{tabular}{cccc}
\hline Trial & $\begin{array}{c}\text { Number } \\
\text { of } \\
\text { trials }\end{array}$ & $\begin{array}{c}\text { MF } \\
\text { permeate flux } \\
\text { mean, } 1 / \mathrm{h}^{2} \mathrm{~m}^{2}\end{array}$ & $\begin{array}{c}\text { UF } \\
\text { permeate flux } \\
\text { mean, } 1 / \mathrm{h} / \mathrm{m}^{2}\end{array}$ \\
\hline 1 & 3 & 93.2 & 43.5 \\
2 & 2 & 88.2 & 45.7 \\
3 & 1 & 87.5 & 40.6 \\
4 & 4 & 64.6 & 32.8 \\
5 & 1 & not done & 18.3 \\
\hline
\end{tabular}


Table 3. Composition of permeate in MF.

\begin{tabular}{lrrrr}
\hline Feed & TS & $\begin{array}{c}\mathrm{P} \\
\text { left from original }\end{array}$ & $\begin{array}{c}\beta-\mathrm{Lg} \\
\text { o-La }\end{array}$ \\
\hline Whey & 100 & 100 & 100 & 100 \\
Trial 1 & 66.8 & 32.1 & 21.2 & 30.2 \\
Trial 2 & 65.8 & 31.6 & 20.7 & 42.3 \\
Trial 3 & 67.7 & 40.7 & 32.4 & 54.4 \\
Trial 4 & 66.1 & 59.2 & 60.7 & 63.3 \\
Trial 5 & 100 & 100 & 100 & 100 \\
\hline
\end{tabular}

TS $=$ total solids $; \mathrm{P}=$ protein content $; \beta-\mathrm{Lg}=\beta$-lactoglobulin; $\alpha$-La $=\alpha$-lactalbumin.

presents the average flux values in the MF trials. The whey in trials 1,2 and 3 had a microfiltration permeate flux about $30 \%$ higher than that in trial 4. In trials 1,2 and $3, \mathrm{CaCl}_{2}$ and $\mathrm{NaOH}$ addition and heat treatment were used before microfiltration. In trial 4 , microfiltration was performed without any pretreatment. In trial 1 , where the method was the same as used by MAUBoIs et al. (1987), the MF fluxes were also similar to their results. It is evident that calcium addition and $\mathrm{pH}$ adjustment together with heat treatment do form aggregates which do not block up the membrane and that the MF fluxes are thereby improved. What we did not have the possibility to do was to use higher flow rates to see their effect on fluxes and permeation.

The composition of the MF permeates is given in Table 3. The total solids content and protein content of the microfiltrate decreased compared to the original whey due to losses in the clarification process. In trials 1 and 2 , about $20 \%$ of $\beta$-lactoglobulin and about $36 \% \alpha$-lactalbumin were filtered into the permeate. In trial 3, 32\% of $\beta$-lactoglobulin and $54 \% \alpha$-lactalbumin, and in trial $4,61 \%$ of $\beta$-lactoglobulin and $63 \% \alpha-$ lactalbumin, were filtered into the permeate. Heat treatment thus formed aggregates, and $\beta$-lg and $\alpha$-la were probably joined to the aggregates, which could explain these results. The side effect of MF can also be seen from the results. Part of $\beta$-lactoglobulin and $\alpha$-lactalbumin is lost into the retentate. If one only looks at this part of

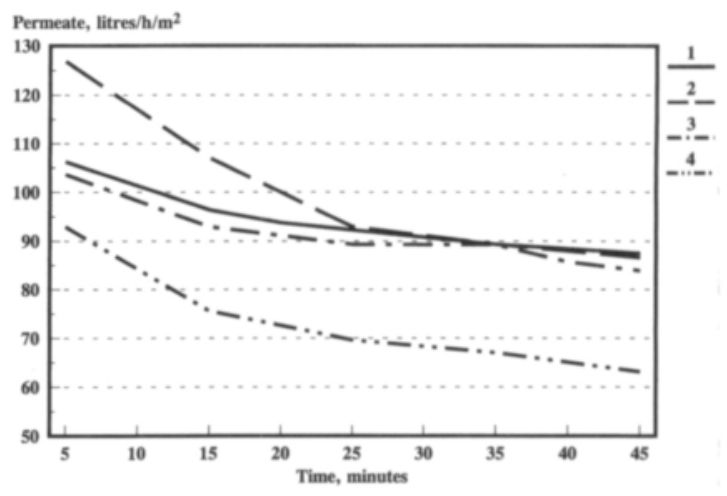

Fig. 2. MF fluxes of edam wheys with different treatments.

the results and not at the fluxes in UF, the best method would be to leave the whey unclarified (trial 5). The figures in Table 3 should not be taken as too exact, because the amounts of whey in the MF run were quite small compared to the capacity of the MF unit. Unfortunately we did not have the possibility to increase the amounts of whey. The original volume of the whey was about 215 litres at the start, and the amount of permeate after the MF run was about 185 litres. However, one can see the effect of the different treatments. Clarification processes have been found to decrease the yield, and heat treatments do it even more compared to untreated and unheated wheys (DAUFIN et al. 1991). It is presumable that the amounts of $\beta$-lactoglobulin and $\alpha$-lactalbumin into the permeate improve when more whey is recycled in the MF unit. In the forthcoming trials we intend to increase the amount of whey from 215 litres to $600-3000$ litres. Also more detailed analyses concerning protein composition must be carried out in future experiments.

Figure 2 shows the microfiltration fluxes during 45 minutes. One can see the problem of membrane fouling during filtration and that fouling increases during the run. $\mathrm{CaCl}_{2}$-added, $\mathrm{pH}$-adjusted and heat-treated wheys (trials 1,2 and 3) have a better performance in MF compared to untreated whey (trial 4). There are variations between the wheys in trials 1, 2 and 3, but during the MF run the variations disappear. 
Table 4. Retentate composition in UF.

\begin{tabular}{lrrrr}
\hline Feed & TS & \multicolumn{1}{c}{$\begin{array}{c}\beta \\
\text { \% left from }\end{array}$} & $\begin{array}{c}\beta \text { - } \mathrm{Lg} \\
\text { orinal }\end{array}$ & $\alpha$-La \\
\hline Whey & 100 & 100 & 100 & 100 \\
Trial 1 & 14.3 & 22.8 & 27.4 & 33.8 \\
Trial 2 & 14.7 & 19 & 13.4 & 35.6 \\
Trial 3 & 19.7 & 27.7 & 35 & 49.6 \\
Trial 4 & 18.1 & 51.9 & 59.7 & 67.9 \\
Trial 5 & 24.3 & 67.6 & 67.3 & 85.7 \\
\hline
\end{tabular}

TS $=$ total solids; $\mathrm{P}=$ protein content $;$ - $\mathrm{Lg}=\beta$-lactoglobulin; $\alpha$-La $=\alpha$-lactalbumin

\section{Ultrafiltration}

Ultrafiltration trials were done using whey which had been microfiltered with a $0.2 \mu \mathrm{m}$ membrane, and the results were compared to those with centrifugally separated whey. The wheys were concentrated six times. Figure 3, which represents UF permeate fluxes in 5 trials, shows the differences in the performance of the wheys. The average fluxes in UF trials are presented in Table 2. The microfiltered whey in trials $1,2,3$ and 4 consistently maintained an ultrafiltration flux about 1.5 to 2.5 higher than that of the separated whey. It is evident that lipids are responsible for the lower permeate flux (MERIN et al. 1983). The higher ultrafiltration permeate flux obtained using microfiltered whey can be explained by the absence of lipids in the feed stream; also the total solids content is lower in the microfiltered wheys. There is also a difference between the three microfiltrated whey ultrafiltration permeate fluxes. $\mathrm{CaCl}_{2}$ addition, $\mathrm{pH}$ adjustment and heat treatment were used in trials 1,2 and 3 . The ultrafiltration permeate fluxes were about $20-40 \%$ higher than that in trial 4 , where only microfiltration was used. This could be explained by the thermocalcic aggregation, occuring after the addition of calcium and $\mathrm{NaOH}$ to produce a $\mathrm{pH}$ of 7.3 , followed by heating. In this process, lipoproteins aggregate through ionic calcium binding, and precipitate. The process is also accompanied by calcium precipitation to cal-

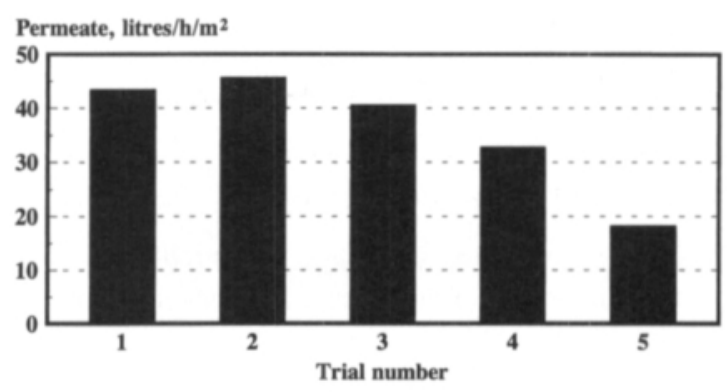

Fig. 3. UF trials with differently treated edam wheys.

cium phosphate. This explains the improvement in flux as compared to microfiltrated whey (DAUFIN et al. 1992). Thus, it seems reasonable to reduce lipid and lipoproteins content of whey before ultrafiltration one way or other. The best methods in this study were those used in trials 1 , 2 and 3 .

The composition of all the UF concentrates is given in Table 4. When looking at them they should be compared to the MF results. The protein content of the concentrate has decreased compared to the microfiltrate. The $\beta$-lactoglobulin and $\alpha$-lactalbumin content is almost the same in UF concentrate as in the microfiltrate trials. There are some variations, but the reliability of these variations should be tested further. Also the FPLC analysis method used for $\beta$-lactoglobulin and $\alpha$ lactalbumin determination may be the source of the unexpected results in the compositions of MF permeates and UF retentates. In the FPLC method a $0.2 \mu \mathrm{m}$ filtration was used before analysis. In our forthcoming experiments we will try to find a better analysis method for this.

The conclusion to be drawn from the results of this study is that microfiltration improves ultrafiltration fluxes, and that the best results are obtained when calcium addition, $\mathrm{pH}$ adjustment and heat treatment are performed before microfiltration. If we consider the resulting amounts of $\beta$ lactoglobulin and $\alpha$-lactalbumin after micro- and ultrafiltration, the best results are obtained without microfiltration or when microfiltration is done 
without any other treatments. The most suitable procedure to try out in the future experiments would seem to be a modification of the microfiltration before ultrafiltration.

\section{References}

Boer, R. de., Wit, J.N. \& Hiddink, J. 1977. Processing of whey by means of membranes and some applications of whey protein concentrate. Journal of Soc. Dairy Technology 30: 112-120.

Daufin, G., Labbe, J.-B., Quemerais, A. \& Michel, F. 1991. Fouling of an inorganic membrane during ultrafiltration of defatted whey protein concentrates. Netherlands Milk and Dairy Journal 45: 259-272.

-, MiChel, F. \& MERIN, U. 1992. Ultrafiltration of defatted whey: Influence of some physicochemical characteristics. Australian Journal of Dairy Technology 47: 7-13.

Fauquant, J., Vieco, E., Brule, G. \& Maubois, J-L. 1985a. Clarification du lactoserums doux par agregation thermocalcique de la matiere grasse residuelle. Lait 65: 1-20.

-, Pierre, A. \& Brule, G. 1985b. Clarification du lactoserum acide de caseinerie. Tech. Lait 1003: 37-41.

Humbrey, R.S. \& Newsome, L.J. 1984. High Performance Ion-Exchange Cromatography of the Major Bovine Milk Proteins. New Zealand Journal of Dairy Science and Technology 19: 197-204.

KeEnAN, T.W., DYLEWSKI, D.P., WOODFORD, T.A. \& FoRD, R.H. 1983. Origin of milk fat globule and and the nature of milk fat globule membrane. In: Fox, P. (ed.). Developments in Dairy Chemistry-2. Applied Science Publishers. p. 83-118.

KITCHEN, B.J. 1974. A comparison of the properties of membranes isolated from bovine skim milk and cream. Biochimica et Biophysica Acta 356: 257-269.

LeE, C.N. \& Merson, R.L. 1976. Prefiltration of cottage cheese whey to reduce fouling of ultrafiltration membranes. Journal of Food Science 41: 403-410.

MaUBoIS, J.L. 1988. Whey, its biotechnical signification. In: Durant et al. (eds.). 8th International Biotechnology Symposium, Paris. Soc. Fr. Microbiol.
-, Pierre, A., Fauquant, J. \& Piot, M. 1986. Industrial fractionation of main whey proteins. International Whey Conference, Chicago.

-, Pierre, A., Fauquant, J. \& Piot, M. 1987. Industrial fractionation of main whey proteins. IDF Bulletin. 212: 154-159.

McDonough, F.E., Hargrove, R.E., Mattingly, W.A., Posati, L.P. \& Alford, J.A. 1974. Composition and Properties of Whey Protein Concentrates from Ultrafiltration. Journal of Dairy Science 57: 1438-1443.

Merin, U. \& Daufin, G. 1990. Crossflow microfiltration in the dairy industry: state-of-the-art. Lait 70: 281291.

-, Gordin, S. \& TAnNy, G.B. 1983. Microfiltration of sweet cheese whey. New Zealand Journal of Dairy Science and Technology 18: 153-160.

Pearce, R.J., Marshall, S.C. \& Dunkerley, J.A. 1991. Reduction of lipids in whey protein concentrates by microfiltration. In: IDF, B-Doc 213. International Dairy Federation Annual Sessions in Tokyo (Japan). Commission B - Technology \& Engineering, Membrane Processing. Progress report of Group B47. p. 76-86.

PIERRE, A. \& FAUQUANT, J. 1986. Principes pour un procede industriel de fractionnement des proteines du lactoserum. Lait 66: 405-419.

-, Legraet, Y., Fauquant, J., Piot, M., Durier, C. \& KOBILINSKY, A. 1992. Evaluation du role des facteurs physicochimiques dans la clarification du lactoserum. Lait 72: 405-420.

Tecator AB. 1975. Manual Kjeltec II. Helsinborg, Sweden.

WIT, J.N. de, 1984. Functional properties of whey proteins in food systems. Netherlands Milk and Dairy Journal 38: 71-89.

Manuscript received March 1993 


\title{
SELOSTUS
}

\section{Juustoheran esikäsittely ennen ultrasuodatusta}

\author{
Tuomo Tupasela, Heikki Koskinen ja Pirkko Antila
}

Maatalouden tutkimuskeskus ja Helsingin yliopisto

Juuston valmistuksen sivutuotteena muodostuu juustoheraa. Juustohera sisăltảả pảảasiassa laktoosia, mutta siină on myös arvokkaita heraproteiineja. Tämän tutkimuksen tarkoituksena oli kehittää proteiinien ensimmäisiä puhdistuksia kalvosuodatuksissa.

Mikrosuodatuskokeissa juustoheroilla, joihin oli lisätty $\mathrm{CaCl}_{2}$ ja NaOH:ta mikrosuodatuksen lisäksi, oli $30 \%$ pa- rempi permeaatin virtaus kuin pelkillä mikrosuodatetuilla heroilla. Ultrasuodatuksessa vertailtiin mikrosuodatettuja heroja normaaliin juustoheraan. Mikrosuodatetuilla heroilla oli 1,5-2,5 kertaa korkeampi UF-vuo kuin normaalilla juustoheralla. Mikrosuodatetuilla heroilla, joissa käytettiin MF:n lisäksi kirkastusta oli UF-vuo 20-40 \% parempi kuin MF heralla. 